\title{
Optical and thermal properties of novel diazine-based oligo(phenylene vinylene)s
}

\author{
Michaël Mainil ${ }^{1,2}$, Laurent Pascal $^{2}$, Jean-Jacques Vanden Eynde ${ }^{2}$, \\ Yves Van Haverbeke ${ }^{2}$, Philippe Dubois ${ }^{1}$ * \\ ${ }^{1}$ Service des Matériaux Polymères et Composites (SMPC), University of \\ Mons-Hainaut, Place du Parc 20, 7000 Mons, Belgium; Fax 0032-65-37 34 84; \\ philippe.dubois@umh.ac.be \\ ${ }^{2}$ Laboratoire de Chimie Organique (LCO), University of Mons-Hainaut, \\ Place du Parc 20, 7000 Mons, Belgium
}

(Received: September 17, 2003; published: October 24, 2003)

\begin{abstract}
New electro-conjugated diazine-based oligo(phenylene vinylene) derivatives with some interesting optical and thermal properties have been synthesised and characterised. These conjugated systems are built up on two benzenic cycles linked to a central diazine, either pyrimidine or pyrazine, through a carbon-carbon double bond. Both benzenic rings are substituted by one or two alkoxy chains. The length, the position and the number of alkoxy chains per benzenic ring have been varied and have proved to modulate both optical and thermal properties. Optical properties have been studied by UV-visible absorption spectroscopy as well as emission spectroscopy. Differential scanning calorimetry, wide-angle X-ray scattering and optical microscopy under crossed polarizers have been applied for characterising the thermal transitions and crystalline changes occurring in these conjugated systems.
\end{abstract}

\section{Introduction}

Over the past 30 years, the world of computer science, telecommunications and, more generally, display devices have known a very impressive expansion. This development follows from the apparition of new efficient microsystems, like solar cells and light-emitting diodes [1]. The active elements of such devices may consist of organic materials like conjugated polymers. These compounds are made of the alternation of single and double bonds that leads to the formation of conjugated $\pi$ molecular orbitals. These orbitals are distributed on different energy levels, whose lowest ones are occupied by $\pi$-electrons (fundamental state). When some electrons pass, after thermal or photonic excitation, from an occupied to an unoccupied level, the conjugated compounds undergo morphological and optical transitions that can be exploited to make electroluminescent devices.

Poly(p-phenylene vinylene) (PPV) [2-4] is the most commonly used conjugated polymer in light-emitting or light-sensitive devices [5] as its electro-optical properties are known to depend on the chain length and the presence of substituents. Practically [6,7], organic light-emitting diodes (LED's) are nowadays made up of thin films of such conjugated polymers sandwiched between metallic electrodes. The 
electrodes are actually able to inject into the organic layer some electrons and holes, which can migrate in opposite directions under a static electric field and then recombine to each other in a luminescent way. In case of photodiodes [8] and other solar cells, binary mixtures of two chemically distinct conjugated systems are able to absorb light. Then, mobile excitons are formed, which can dissociate at the molecular interface into charge carriers that move away from each other up to the electrodes [9] and an electrical current is generated.

The design of efficient LED's and photodiodes requires thus to tailor the electronic structure of the conjugated molecules in order to tune properly the energy of the frontier electronic levels. It is needed to adjust the energy levels of the fundamental and excited states to modulate the colour of the light emitted by such display devices. Pascal et al. [10] have recently shown that various derivatization schemes can be quantified and exploited to modulate the energies of the frontier levels of oligo-PPV containing nitrogen atoms (see Fig. 1). More precisely, it appears that the meta connections on the central cycle of the oligo-PPV lead to a diminution of the lowest energy of optical transition. Moreover, experimental and theoretical results have shown that the $\pi$-donor character of methoxy groups [11] fitted to the oligo-PPV acts also upon the electro-optical properties of the conjugated systems.

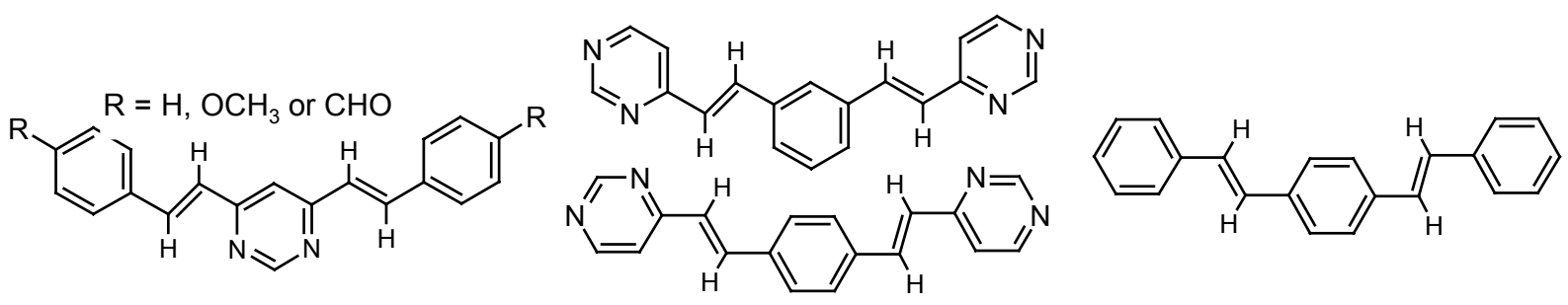

Fig. 1. Typical tailored diazine-containing oligo(phenylene vinylene)s and modelled oligo-PPV [10]

There are multiple reasons for working with such short conjugated hetero-chains (oligomer approach). Oligomers are more soluble in common organic solvents than homologous polymers and can thus be readily analysed by spectroscopic methods. Furthermore, it has been shown that the energies of optical transitions of short oligo( $p$-phenylene vinylene)s are higher than those of longer chains [5]. Moreover, the incorporation of meta bonds in the PPV backbone implies a lowering of the molecular conjugation. Both effects allow the conjugated systems to emit blue light $[5,9]$, the primary colour that is the less easily obtained in electroluminescent diodes containing conjugated polymers. Interestingly enough, the introduction of nitrogen atoms in the cycles of the oligo-PPV has been reported to increase at the same time the ionisation potential and the electronic affinity of such compounds [12]. These conjugated systems a priori could act as electron-transporting layers in LED's or as electron-withdrawing layers in photodiodes [13,14].

On the basis of these works, this paper aims at reporting on the synthesis of new short conjugated systems wherein two benzenic cycles substituted by one (or two) alkoxy chains are linked to each other via a diazine (pyrimidine or pyrazine) cycle and carbon-carbon double bonds (the general formula is given in Fig. 2). All these heteroconjugated derivatives have first been characterised by UV-visible absorption and emission spectroscopies. Their thermal properties have been also investigated by differential scanning calorimetry (DSC), optical microscopy under crossed polarizers 
and wide-angle X-ray spectroscopy (WAXS). Such compounds possess a rigid core and flexible side chains that could exhibit some original thermal properties like polymorphism [15] or liquid crystal behaviour [16,17]. Indeed, it is known from literature that some rigid conjugated compounds grafted with flexible alkoxy chains [18] can display liquid crystal behaviour. Moreover, Mataka et al. [19] prepared nitrogenated heterocycles carrying benzenic cycles substituted by different alkoxy chains. It appears that a methoxy substitution does not lead to liquid crystal behaviour, whereas, when longer alkoxy chains are used, i.e., butoxy or octyloxy chains, mesophases are formed. On the other hand, let us note that some poly(pyridylvinylene phenylvinylene)s have shown liquid crystal behaviour as well [20].

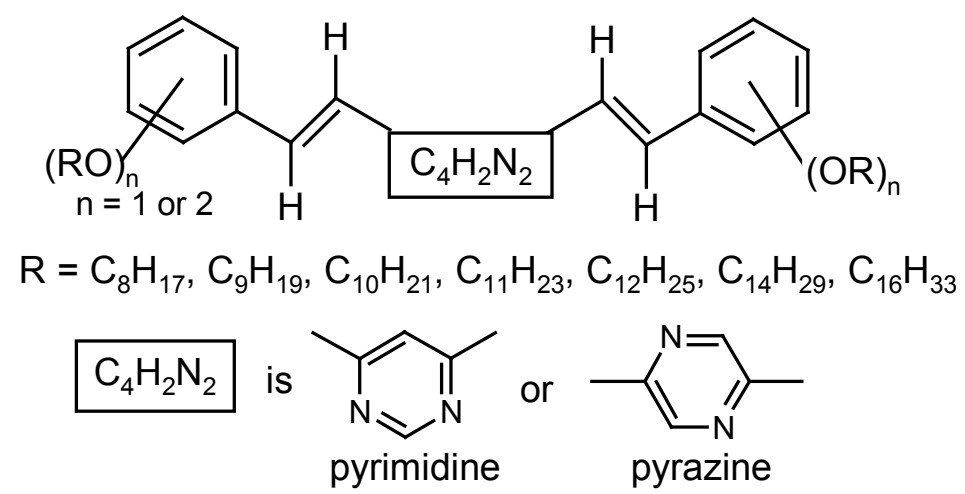

Fig. 2. General formula of the synthesized diazine-based compounds

Alkoxy-substituted diazine-based conjugated compounds

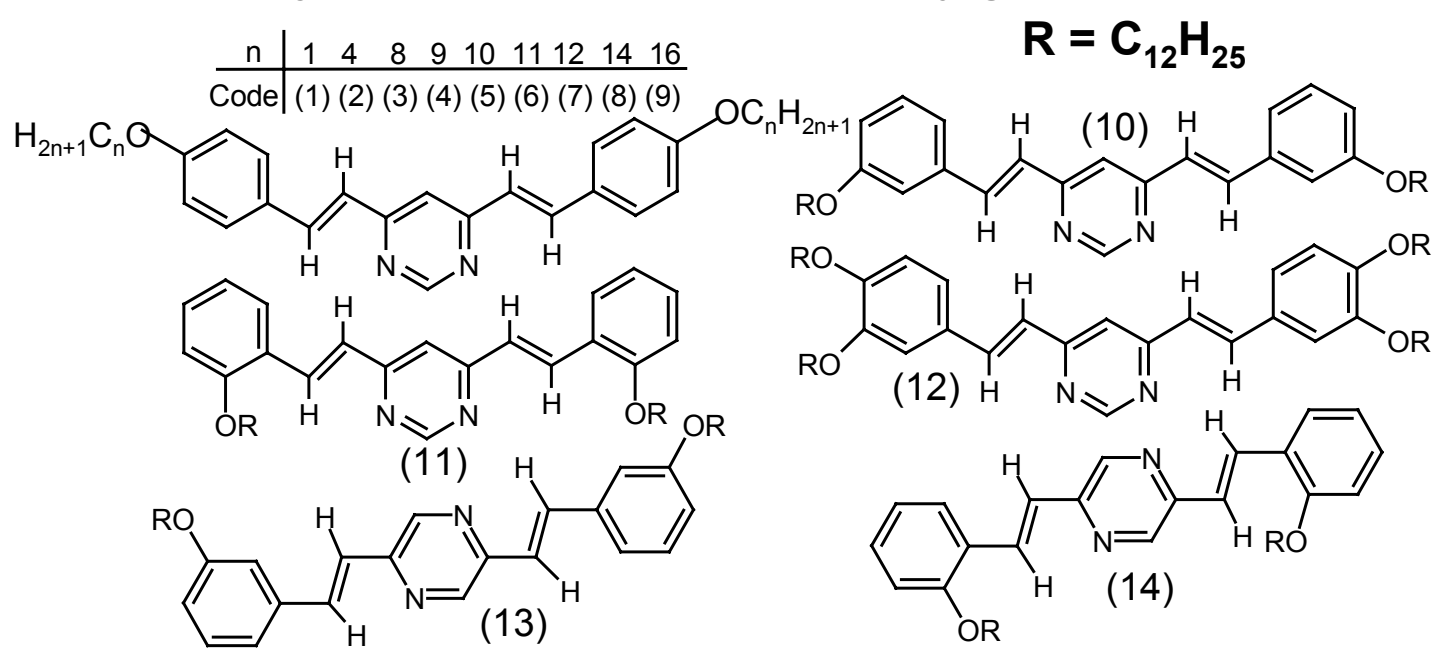

Reference unsubstituted compounds [10]<smiles>C(=C/c1cc(/C=C/c2ccccc2)ncn1)\c1ccccc1</smiles><smiles>C(=C/c1ccncn1)\c1cccc(/C=C/c2ccncn2)c1</smiles>

Fig. 3. Structure of the synthesized conjugated systems 


\section{Results and discussion}

The studied conjugated heterocyclic compounds are made up of a central heterocycle - a pyrimidine or a pyrazine - supporting through two carbon-carbon double bonds two benzenic cycles, each one grafted by one or two alkoxy chains. The actual structures of the synthesised molecules $(3-14)$ are shown in Fig. 3 together with previously reported derivatives $(1,2,15-17)$ [10], presented here for the sake of comparison.

Such molecular architecture formally results from an aldolic condensation reaction between a dimethyldiazine, i.e., 4,6-dimethylpyrimidine or 2,5-dimethylpyrazine, and an $\mathrm{O}$-alkylated aromatic aldehyde prepared via O-alkylation of a hydroxybenzaldehyde (see general scheme in Fig. 4). These two consecutive reactions interestingly occur in $5 \mathrm{M} \mathrm{NaOH}$ and in the presence of a catalytic amount of tetrabutylammonium hydrogen sulfate. Indeed, recent works [21] allow to envisage that certain (di)methyldiazines can readily react by aldolic condensation with aromatic (di)aldehydes under such experimental conditions, thus without any organic solvent. Furthermore, it has been proved that hydroxybenzaldehydes can easily be $O$-alkylated under the same reaction conditions as well [22].
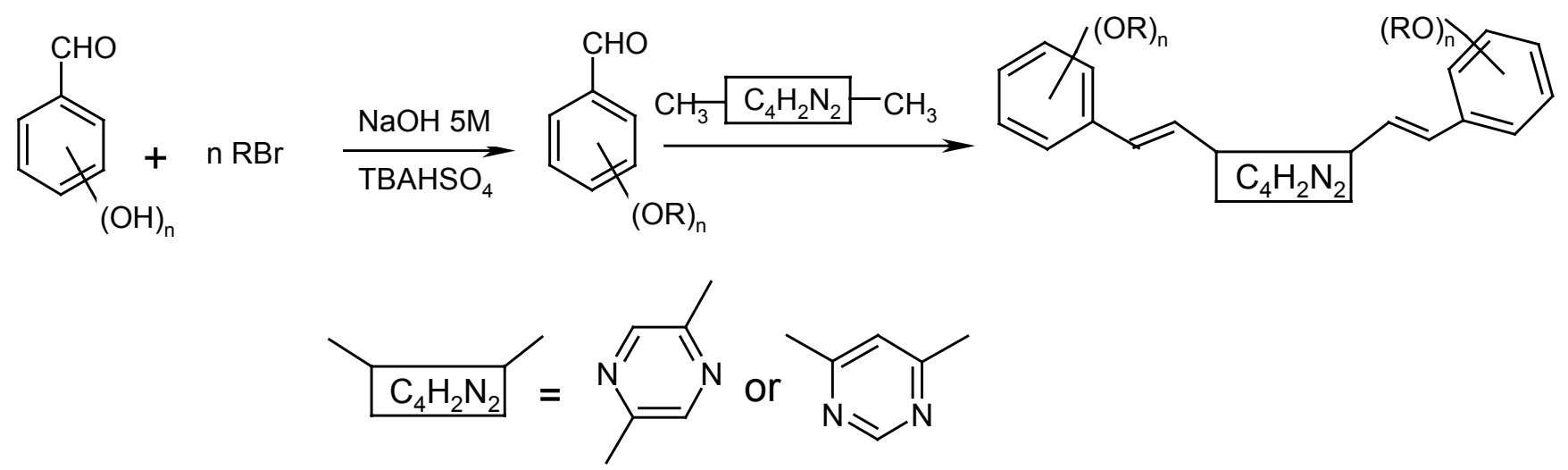

Fig. 4. General scheme for the synthesis of compounds 1 to 14

The condensation and O-alkylation steps imply that two synthetic pathways are possible to obtain the targeted conjugated compounds (see Fig. 5). The first way consists in alkylating the hydroxybenzaldehyde by an alkyl halide in the first step and then to perform the condensation with the heterocycle. Following the second way, the hydroxybenzaldehyde can react first with the heterocycle and the resulting condensation product is then alkylated. We investigated the efficiency of both approaches in preparing a simpler model compound, 4-[2-(4-octyloxyphenyl)ethenyl]pyrimidine, starting from 4-methylpyrimidine, 4-hydroxybenzaldehyde and bromooctane. The reactions were carried out in a hot aqueous solution of $5 \mathrm{M}$ sodium hydroxide containing $10 \mathrm{~mol}-\%$ tetrabutylammonium hydrogen sulfate.

The efficiency of benzaldehyde alkylation (way 1 ) was evaluated in stirring 4-hydroxybenzaldehyde and bromooctane in the boiling aqueous solution for $8 \mathrm{~h}$. After cooling, an oil could be isolated and was identified as 4-octyloxybenzaldehyde. The reaction yield was higher than $90 \%$ indicating that the alkylation reaction of the benzaldehyde was (almost) complete. The reaction time could be reduced to $1 \mathrm{~h}$ without affecting noticeably the synthesis efficiency, as already observed by Vanden Eynde et al. [22] 
<smiles>CCOc1ccc(/C=C/c2ccncn2)cc1/C=C/c1ccc(/C=C/c2ccc(O)cc2)cc1/C=C/c1ccncn1</smiles>

Fig. 5. Two possible synthetic schemes for obtaining the targeted conjugated compounds

The condensation reaction between the so-obtained 4-octyloxybenzaldehyde and 4-methylpyrimidine has been carried out for $8 \mathrm{~h}$ in the boiling aqueous solution. After cooling, a product could be isolated, which was identified as 4-[2-(4-octyloxyphenyl)ethenyl]pyrimidine. The yield of the condensation reaction was again $90 \%$. The reaction time could be reduced to $1 \mathrm{~h}$ without affecting noticeably the synthesis efficiency as well.

As far as pathway 2 is concerned, the hydroxybenzaldehyde alkylation was first evaluated by stirring 4-hydroxybenzaldehyde and 4-methylpyrimidine in the boiling aqueous solution for $8 \mathrm{~h}$. After cooling, a precipitate could be isolated and then identified, following the information given in the literature, as the expected 4-[2-(4hydroxyphenyl)ethenyl]pyrimidine, with a modest recovery yield of about $25 \%$.

Therefore and under very similar experimental conditions, it comes out that synthesis pathway 1 (see Fig. 5), relying on the consecutive O-alkylation of 4-hydroxybenzaldehyde and then the condensation of 4-octyloxybenzaldehyde with 4-methylpyrimidine is by far more efficient (overall yield $>90 \%$ ) compared to way 2 (where a yield of $25 \%$ is obtained for the first reaction step only). Interestingly, it has been proposed to synthesise the targeted pyrimidine-based compounds without isolation of the intermediate aldehyde ('one pot synthesis') by stirring a mixture of hydroxybenzaldehyde, alkyl bromide and 4,6-dimethylpyrimidine in a boiling aqueous solution of $5 \mathrm{M}$ sodium hydroxide for $1 \mathrm{~h}$ in the presence of a catalytic amount of tetrabutylammonium hydrogen sulfate (10 mol-\%, with respect to the aldehyde). All targeted derivatives (3 - 12) were recovered within good yields except for the pyrazine-based compounds (13 and 14), which require a modification of the experimental protocol. Because of the lower reactivity of 2,5-dimethylpyrazine towards aromatic aldehydes (compared to 4,6-dimethylpyrimidine [21]), the engaged aldehyde underwent a competitive Cannizzaro dismutation [24], what noticeably limited the yield in condensation products. Thus, to obtain the pyrazine-based compounds 13 and 14, we had to prepare in a first step the 2-dodecyloxybenzaldehyde and 3-dodecyloxybenzaldehyde by $O$-alkylation of the respective 2- and 3-hydroxybenzaldehydes. These alkylated compounds without any intermediate purification step were then directly introduced by small portions, for $8 \mathrm{~h}$, into the boiling aqueous solution containing 2,5 -dimethylpyrazine. The reaction yields in pyrazine-based compounds were $30 \%$ in both cases.

\section{Study of the optical properties}

The optical properties of the new compounds described in Fig. 3 have been studied by UV-visible absorption and emission spectroscopies. We investigate here the potential effects of the alkoxy chains on the optical properties of the tailored oligoPPV. Recent results show that the introduction of alkoxy groups on the oligo-PPV 
backbone has a noticeable effect on the optical transition energies [11]. Indeed, the optical transition of lowest energy measured for the 2,5,2",5"-tetramethoxy-1,3-di-(2phenylethenyl)benzene (see Fig. 6) appears at a lower value compared to the corresponding unsubstituted oligomer (15).

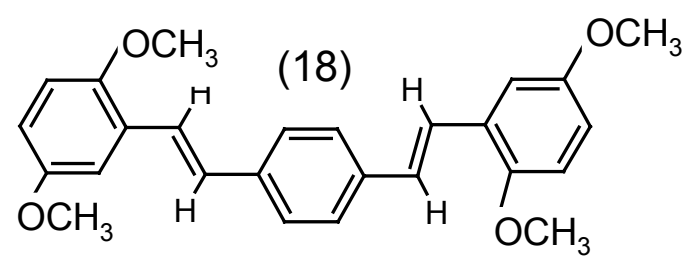

Fig. 6. Molecular structure of 2,5,2",5"-tetramethoxy-1,3-di(2-phenylethenyl)benzene

The UV-visible absorption and emission spectra of all the conjugated systems have been recorded in dichloromethane $\left(2 \cdot 10^{-5} \mathrm{M}\right)$. Tab. 1 summarises the absorption and emission wavelengths characterising the lowest optical transition and the associated molar extinction coefficients. The ensuing results are complementary to those recently reported by Pascal et al. [10] for comparative reference compounds (see bottom of Fig. 3).

Tab. 1. Absorption and emission wavelengths corresponding to the lowest optical transition and the associated molar extinction coefficients $\left(\varepsilon_{\max }\right.$ expressed in $\left.\mathrm{L} /(\mathrm{mol} \cdot \mathrm{cm})\right)$

\begin{tabular}{cccccccc}
\hline Compound & \multicolumn{2}{c}{ Absorption } & Emission & Compound & \multicolumn{2}{c}{ Absorption } & Emission \\
& $10^{-3} \cdot \varepsilon_{\max }$ & $\lambda_{\max } / \mathrm{nm}$ & $\lambda_{\max } / \mathrm{nm}$ & & $10^{-3} \cdot \varepsilon_{\max }$ & $\lambda_{\text {max }} / \mathrm{nm}$ & $\lambda_{\text {max }} / \mathrm{nm}$ \\
\hline 15 & 38 & 345 & 396 & 7 & 36 & 366 & 442 \\
16 & 53 & 315 & 388 & 8 & 40 & 366 & - \\
17 & 51 & 361 & 407 & 9 & 38 & 365 & - \\
1 & 38 & 360 & 440 & 10 & 36 & 351 & 416 \\
3 & 39 & 366 & - & 11 & 35 & 364 & 434 \\
4 & 40 & 367 & - & 12 & 37 & 376 & 473 \\
5 & 36 & 366 & - & 13 & 46 & 387 & 440 \\
6 & 38 & 366 & - & 14 & 42 & 395 & 456
\end{tabular}

\section{Effect of benzenic cycle substitution by alkoxy chains}

The introduction of an alkoxy chain on the benzenic cycles leads to a weak red shift effect with respect to the unsubstituted molecule (15), the $\lambda_{\max }$ value of which is 345 $\mathrm{nm}$ as determined by UV-visible absorption. This observation can theoretically be explained by the fact that the alkoxy chains as efficient electro-donor substituents lead to an asymmetric destabilization of the HOMO and LUMO energy levels. In consequence, the band gap is reduced and the wavelengths are shifted to the red colour. Pascal et al. [10] also observed a slight red shift when attaching methoxy groups on the terminal carbons of 15 . This red shift is more emphasized when the alkoxy chains are located in para (1 to $\mathbf{9})$ or in ortho (11) position with respect to exocyclic double bonds: this red shift is close to $20 \mathrm{~nm}$ in comparison to 15 . When 
the alkoxy chain is fixed on the meta position (10), this red shift is limited to $5 \mathrm{~nm}$ as the electro-donor mesomer group does not take part in the conjugation extension of the system. When two alkoxy chains are fitted on the benzenic cycles, in both meta and para positions with respect to the exocyclic carbon-carbon double bond (12), $\lambda_{\max }$ reaches $376 \mathrm{~nm}$.

As far as the alkoxy chain length is concerned, that is to say comparing compounds 1 to 9 , which are substituted by two alkoxy chains attached in para position of the benzenic cycles with respect to the exocyclic carbon-carbon double bonds, they all show identical absorption spectra (same plot shape, $\lambda_{\max }$ and $\varepsilon_{\max }$ ). The number of carbon atoms of the alkoxy chains has no influence on the optical properties of the studied compounds. This observation is not that much surprising insofar as the alkyl chains of the alkoxy groups do not take part to the electronic delocalisation of the molecules, which is related to the optical transition energies.

\section{Effect of para connection to the inner heterocycle}

We previously observed [10] (see Tab. 1) that compounds 16 and 17 have a similar intensity for the absorption corresponding to the band gap of the lowest energy, but that a red shift of about $46 \mathrm{~nm}$ occurs when passing from 16 to 17. It comes out that the meta connection of the two aromatic cycles onto the inner cycle breaks down the delocalisation of the electronic wave function initially existing along the 'para' molecule and therefore limits noticeably the red shift effect as the number of cycles grows. Similarly, Karabunarliev et al. [25] reported that the red shift observed by increasing the number of cycles is more pronounced for oligo( $p$-phenylene vinylene $) \mathrm{s}$ than for $m$-phenylene vinylenes.

Similarly, it appears that the pyrazine-based compounds 13 and 14 have a lower energy of optical transition than their equivalent compounds articulated on a pyrimidine cycle. This observation can be explained as well by the characteristic para geometry of the pyrazine-substituted compounds compared to the meta geometry of the pyrimidine-based compounds. Moreover, we found out that compound 14, where the alkoxy chains are attached in ortho position with respect to the exocyclic double bonds, has a lower energy of optical transition than the meta-substituted one (13), similarly to the above discussed compounds 10 and 11.

The results provided by emission spectroscopy indicate very similar tendencies to the data gathered by absorption spectroscopy. Indeed, it seems that the position and the number of alkoxy groups on the benzenic cycles display the same effect on $\lambda_{\max }$ as already discussed above. In both cases, the pyzazine-based compounds 13 and 14 have $\lambda_{\max }$ values higher by about $20 \mathrm{~nm}$ than $\lambda_{\max }$ recorded for the pyrimidine-based compounds.

\section{Study of the thermal properties}

The association within the same molecule of two extreme types of molecular structure, namely a rigid conjugated central core (aromatic cycles interconnected by ethenyl bonds) supporting lateral and flexible alkoxy chains, is likely to induce specific thermal behaviour as, i.e., mesophase formation or polymorphism. We investigated the effects of the length, the position and the number of the alkoxy chains on the thermal properties of the diazine-based compounds. All the studied compounds have been characterised by differential scanning calorimetry (DSC), 
following a scanning (heating/cooling) rate of $10^{\circ} \mathrm{C} / \mathrm{min}$. In some cases, the thermal behaviour of the conjugated compounds is characterised by more than one thermal transition; the temperature of the last thermal transition recorded upon heating is indicated for each molecule in Tab. 2. Optical microscopy under crossed polarizers and X-ray diffraction at wide angles (WAXS) have been also carried out as complementary analyses in order to detect, respectively, a possible mesophase formation or polymorphic transitions occurring with temperature change.

Tab. 2. Highest recorded melting temperature of the alkoxy para-substituted pyrimidine-based conjugated compounds upon heating (DSC heating rate: $10^{\circ} \mathrm{C} / \mathrm{min}$ )

\begin{tabular}{cccccc}
\hline Compound & $\begin{array}{c}\text { Alkoxy } \\
\text { chains }{ }^{\mathrm{a}}\end{array}$ & $\begin{array}{c}T_{\mathrm{m}} \\
\text { in }{ }^{\circ} \mathrm{C}\end{array}$ & Compound & $\begin{array}{c}\text { Alkoxy } \\
\text { chains }{ }^{\mathrm{a}}\end{array}$ & $\begin{array}{c}T_{\mathrm{m}} \\
\text { in }{ }^{\circ} \mathrm{C}\end{array}$ \\
\hline 1 & 1 & 185.5 & 6 & 11 & 120.6 \\
2 & 4 & 141.0 & 7 & 12 & 118.0 \\
3 & 8 & 126.6 & 8 & 14 & 119.2 \\
4 & 9 & 126.3 & 9 & 16 & 114.6 \\
5 & 10 & 114.0 & 12 & $12^{\mathrm{b}}$ & 88.5 \\
of carbon atoms per alkoxy chain. & ${ }^{\mathrm{b}}$ Disubstituted derivative.
\end{tabular}

\section{Effect of the position of the alkoxy chains substituting the benzenic cycles}

For alkoxy chains made of 12 carbon atoms, the thermograms of the meta- and ortho-substituted pyrimidine-based molecules 10 and 11 showed only one thermal transition recorded at 79.2 and $58.5^{\circ} \mathrm{C}$, respectively, which is actually characteristic of sample melting (Fig. $7 a$ and b). Neither liquid crystal nor polymorph behaviour is thus expected for these compounds. However, the position of the alkoxy chain on the benzenic cycles plays a key-role on the thermal properties. For instance, when the chains shift on the benzenic cycles from the meta to the ortho position, the melting temperature decreases from $79.2^{\circ} \mathrm{C}$ down to $58.5^{\circ} \mathrm{C}$. These results are confirmed by the melting of the para-substituted pyrimidine-based conjugated derivative 7 , which takes place at a higher temperature equal to $118.0^{\circ} \mathrm{C}$. The meta and ortho substitutions are thus likely to induce some steric effect, which could disturb the molecular configuration in the crystal lattice with a resulting lower melting temperature. Optical microscopy observations under crossed polarizers showed no birefringence modifications with temperature increase (or decrease), indicating the absence of any liquid crystal phase formation and confirming the DSC results.

Similarly to derivatives 10 and 11 , the thermograms of the pyrazine-based compounds 13 and 14, again substituted by dodecyloxy chains fitted to the benzenic rings in meta and ortho position, respectively, show one single thermal transition, related to a simple melting at 98.3 and $90.0^{\circ} \mathrm{C}$, respectively. Similarly to the pyrimidine-based compounds, the melting temperature decreases when the chain shifts from meta to ortho position on the benzenic cycles. Nevertheless, it is worthy to note that the melting temperatures of the pyrazine-based compounds are higher than those recorded for the corresponding pyrimidine-based counterpart. This observation could be explained by the more linear configuration of the pyrazine-based compounds where the styryl moieties are fixed in para position to the core heterocycle. Let us note that 13 and $\mathbf{1 4}$ have also been observed by optical microscopy under 
crossed polarizers and that no characteristic modification of the birefringence could be detected by changing the temperature.
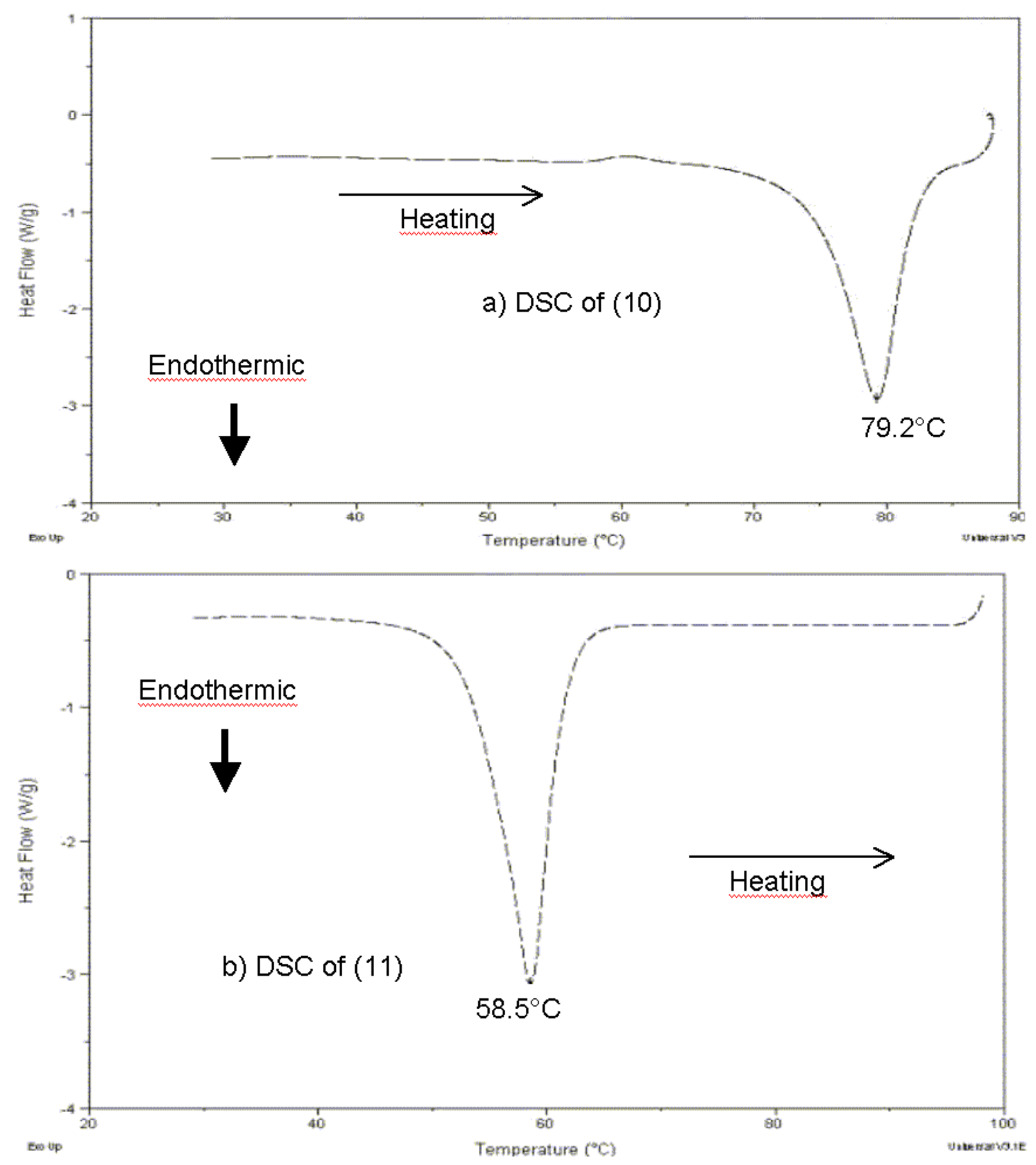

Fig. 7. DSC thermograms of the meta (a) and the ortho (b) dodecyloxy-substituted pyrimidine-based compounds 10 and 11 (heating rate: $10^{\circ} \mathrm{C} / \mathrm{min}$ )

\section{Effect of chain length of alkoxy groups substituting the benzenic cycles}

The chain length effect was studied only for the pyrimidine-based compounds wherein the alkoxy chains are attached in para position to the benzenic rings. It results that every compound ranging from 3 to 9 displays three (or even four) firstorder thermal transitions (see Fig. 8, showing typical thermograms for the octyloxyand the hexadecyloxy-substituted pyrimidine-based compounds 3 and 9). These thermal transitions get closer to each other as the number of carbon atoms increases. This thermal behaviour has proved independent of the heating rate $\left(10^{\circ} \mathrm{C} / \mathrm{min}\right.$ or $\left.5^{\circ} \mathrm{C} / \mathrm{min}\right)$. The highest thermal transitions of the studied molecules are 
all ranging from 116 to $128^{\circ} \mathrm{C}$. It is worth pointing out that equivalent compounds with shorter chains (methoxy, 1, and butoxy, 2) display only one melting transition, which occurs, respectively, at 188.5 and $141.0^{\circ} \mathrm{C}$. We can conclude that, as reported in refs. [16-19], when increasing the alkoxy chain length, the molecules become more flexible and melt at lower temperature. The melting temperature decreases quickly with chain length from more than $180^{\circ} \mathrm{C}$ down to $\mathrm{C} .120^{\circ} \mathrm{C}$ where it stabilizes for chains made of at least 11 carbon atoms. Actually, the observation of more than one first-order thermal transition for compounds $\mathbf{3}$ to $\mathbf{9}$ might be correlated to either mesophase formation or polymorphism.
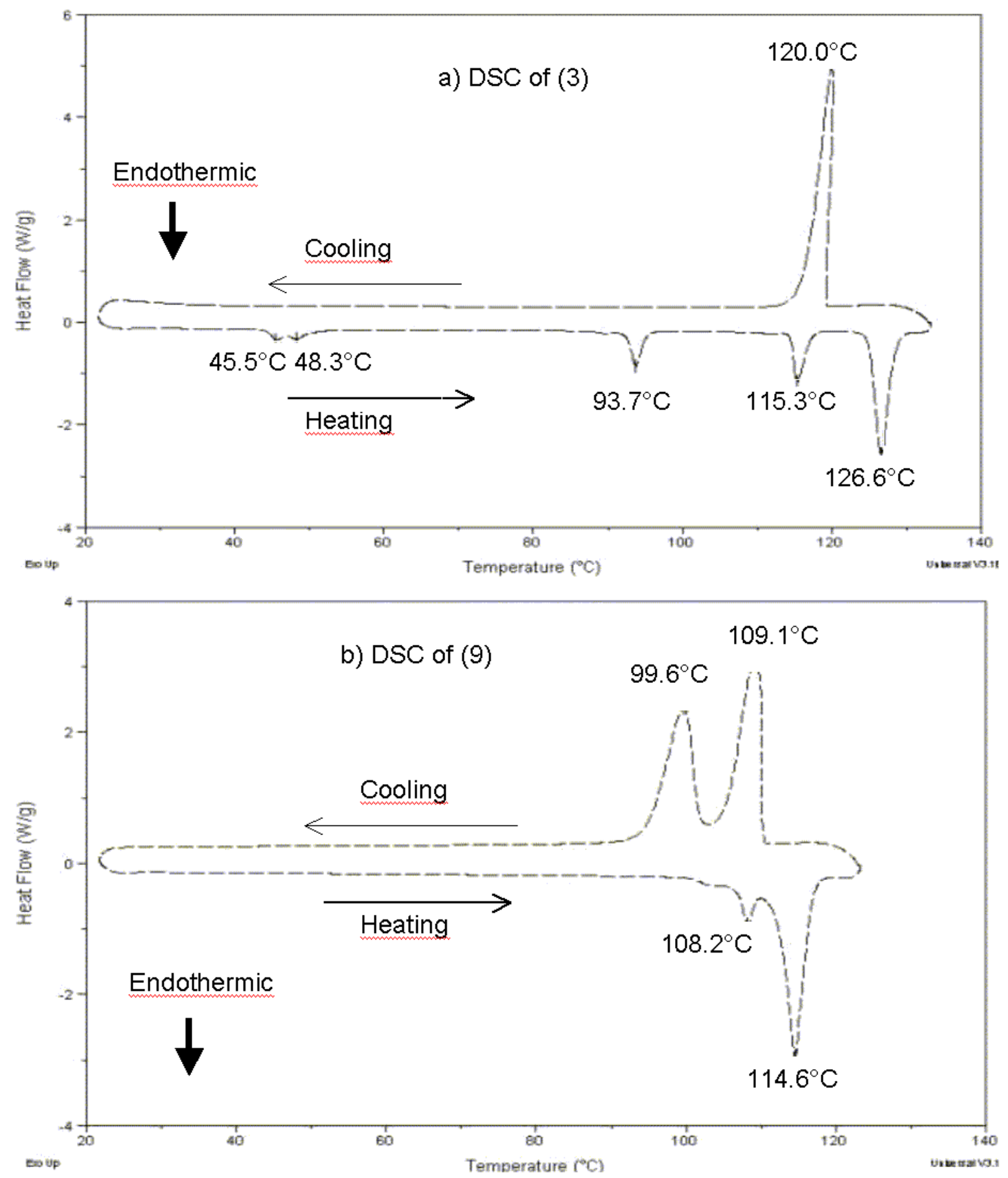

Fig. 8. DSC thermograms of the (a) octyloxy- and (b) hexadecyloxy-substituted pyrimidine-based compounds 3 and 11 (heating and cooling rate: $10^{\circ} \mathrm{C} / \mathrm{min}$ ) 

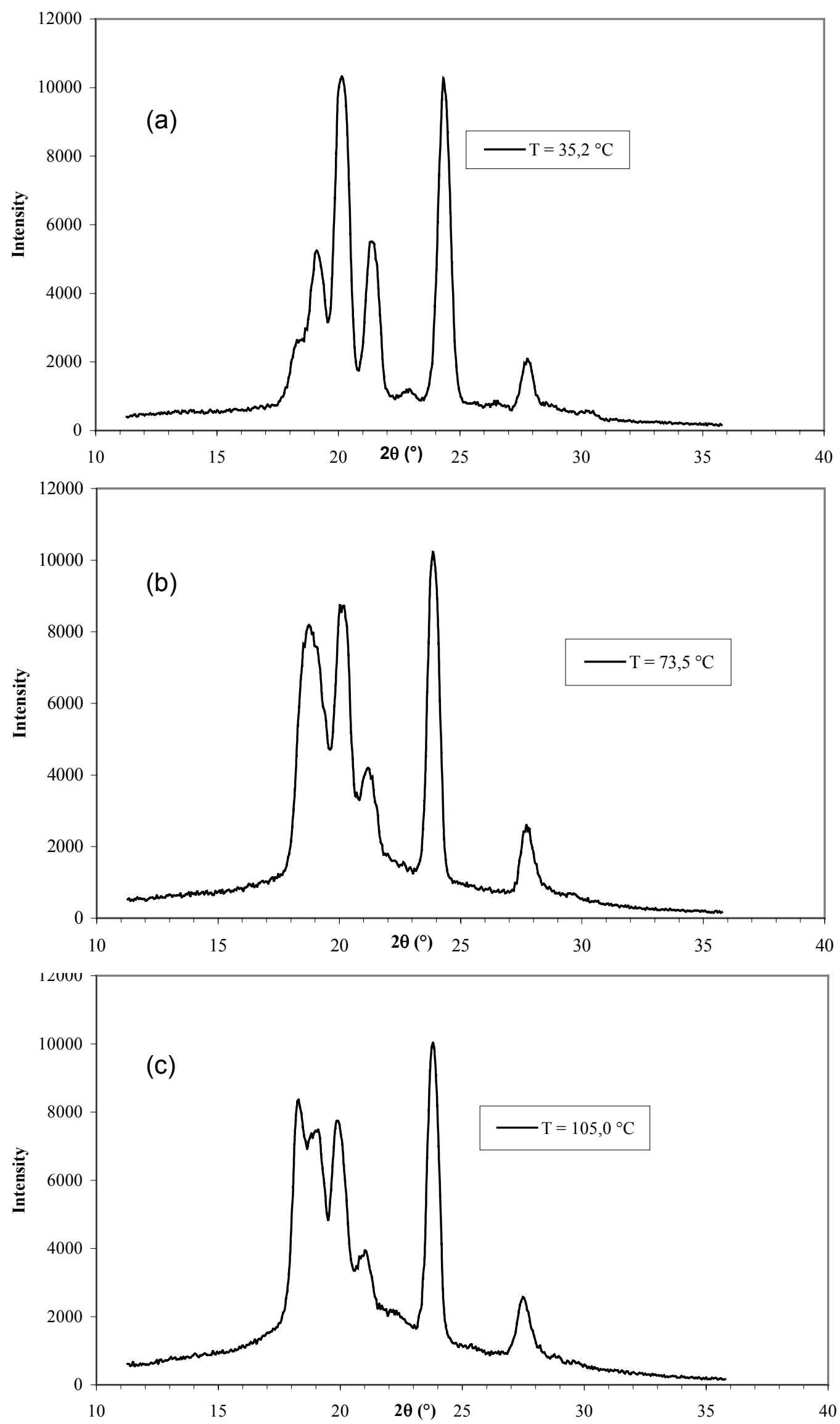

Fig. 9. WAXS diffractograms of the octyl-substituted pyrimidine-based conjugated compound 3 recorded at different temperatures (Fig. 9d cf. next page) 


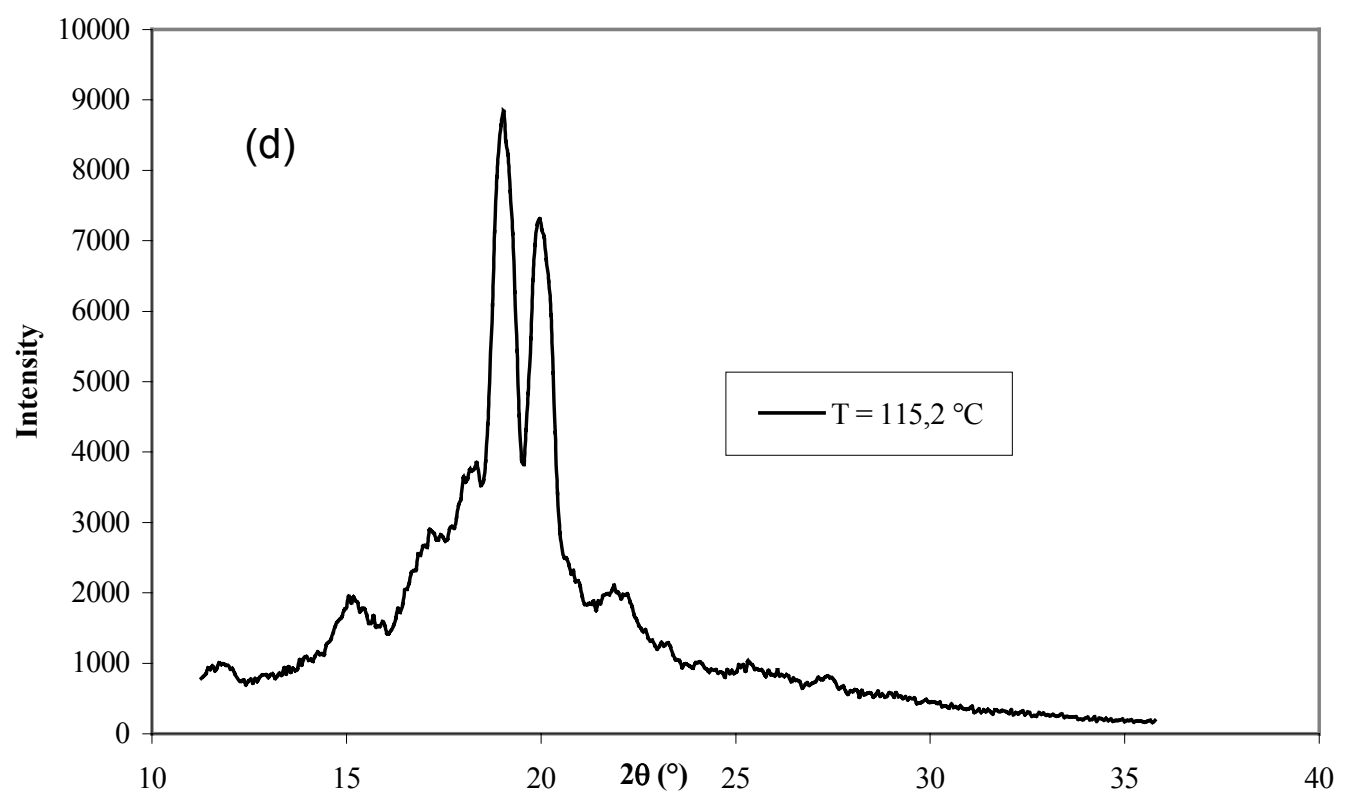

Fig. 9d.

Interestingly, observations with optical microscopy under crossed polarizers have not shown any characteristic birefringence modifications by changing the temperature, which therefore exclude the presence of liquid crystal structures. Accordingly, the thermal transitions detected by DSC could be correlated to allotropic transitions between different crystalline structures. In order to shed some light on this hypothesis, compound 3 has been analysed by WAXS at different temperatures (35.2, 73.5, 105.2 and $115.2^{\circ} \mathrm{C}$ ) located in between all the first-order thermal transitions recorded by DSC with a heating rate of $10^{\circ} \mathrm{C} / \mathrm{min}$ (see Fig. 9a to d). Clearly, the variation visible in the recorded diffractograms implies allotropic transformations and gives credit to the formation of polymorphic compounds. Identifying the actual nature of the crystal lattices was out of the scope of this study and was not carried out.

\section{Effect of the number of alkoxy chains substituting the benzenic cycles}

Compound 12 is characterized by two alkoxy chains each made of 12 carbon atoms and attached on the benzenic rings in meta and para positions. This architecture might display some characteristic thermal features common to both compounds 7 and 10. The DSC thermogram of 12 shows actually two transitions located at 77.1 and $88.5^{\circ} \mathrm{C}$ (Fig. 10). As already observed, the chain fixed in meta position tends to reduce the temperature of the thermal transitions in comparison to its para-substituted counterpart.

Observations by optical microscopy under crossed polarizers have not shown any characteristic birefringence modification with temperature. No liquid crystal structures should thus be expected. On the other hand, two distinct melting transitions are clearly visible by optical microscopy under crossed polarizers at the transition temperatures recorded by DSC. This involves that this double first-order thermal transition is likely related to a polymorph behaviour, which appears to be a characteristic feature of the long alkoxy para-substituted compounds. 


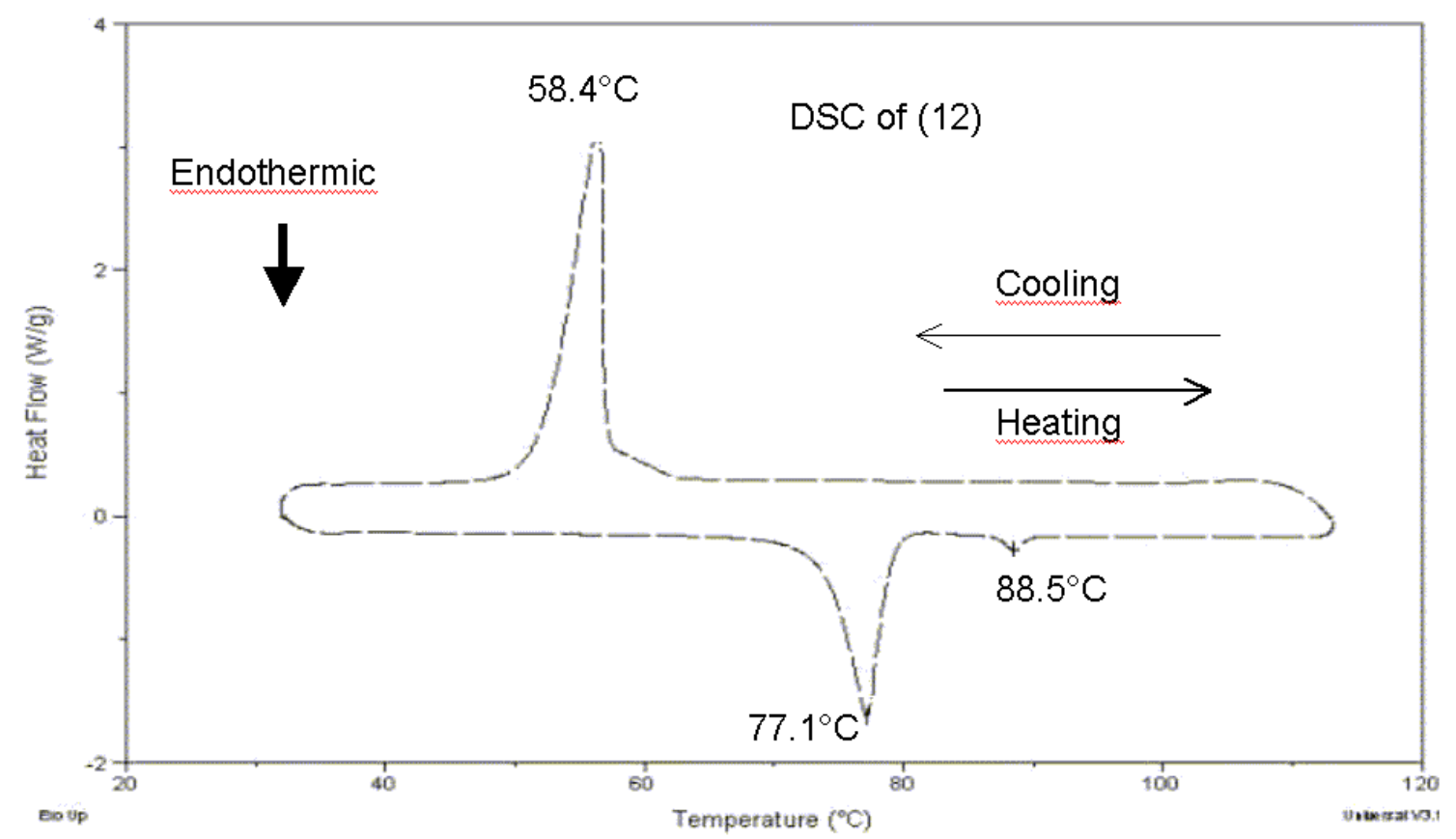

Fig. 10. DSC thermograms of the dodecyloxy-disubstituted pyrimidine-based compound 12 (heating and cooling rate: $10^{\circ} \mathrm{C} / \mathrm{min}$ )

\section{Conclusions and perspectives}

New electro-conjugated diazine-based compounds displaying some interesting optical and thermal properties have been synthesised and characterised. These conjugated systems are made of two benzenic cycles linked to a central diazine (pyrimidine or pyrazine) via a carbon-carbon double bond. Both the benzenic rings are fitted with one or two alkoxy chains. The length, the position and the number of alkoxy chains per benzenic ring have been varied and have shown to be able to modulate the optical and thermal properties.

The experimental protocol investigated to synthesise the targeted compounds is straightforward and rather economic since it does not require any organic solvent. It relies upon an aldolic condensation of a dimethyldiazine (4,6-dimethylpyrimidine or 2,5-dimethylpyrazine) with an aromatic aldehyde in a boiling aqueous solution of $5 \mathrm{M}$ sodium hydroxide and in the presence of a quaternary ammonium salt.

UV-visible absorption spectroscopy has shown that the optical properties of the different molecules can be modulated by varying the position and the number of alkoxy chains grafted on the benzenic cycles. Indeed, in case of the pyrimidine-based compounds, a red-shift of about $20 \mathrm{~nm}$ is observed in comparison with the nonsubstituted compound, when the alkoxy chains are anchored in para or ortho position of the benzenic cycles. When attached in meta position, the alkoxy chains lead to a red-shift of only $5 \mathrm{~nm}$. This effect is more marked for the pyrazine-based compounds. As expected, the length of the alkoxy chains has no noticeable effect on the optical properties. A similar behaviour was recorded by emission spectroscopy.

The thermal properties can also be modulated not only by the position or the number of the alkoxy chains, but also by their length as evidenced by DSC. Indeed, increasing the number of carbon atoms in the alkoxy chains leads to a noticeable decrease of the melting temperature. Such an effect is also observed when the alkoxy chain shifts from para to ortho position on the benzenic cycle. In that way, the melting temperature of the studied conjugated system can be tuned from about $50^{\circ} \mathrm{C}$ to $190^{\circ} \mathrm{C}$. 
Some observations by optical microscopy under crossed polarizers allow us to exclude any formation of liquid crystal phases amongst the prepared compounds. Nevertheless, the pyrimidine-based systems, 'para' substituted by alkoxy chains with at least 8 carbon atoms, are polymorphic compounds, as attested by DSC and WAXS performed at different temperatures.

This study paves the way to the development of novel oligo(phenylene vinylene) derivatives with interesting modulated electro-optical and thermal properties. Indeed, future works will concentrate on the synthesis of longer conjugated oligomers by extrapolating the strategy to (poly)condensation reactions between dimethyldiazines and aromatic dialdehydes.

\section{Experimental part}

\section{Materials and characterisation}

All solvents and reagents are commercially available and were used as received from Acros Organics Chem-Lab N.V. NMR spectra were recorded on a Jeol JNP-PMX60 spectrometer $\left(60 \mathrm{MHz}\right.$ for ${ }^{1} \mathrm{H}$ in a magnetic field of $\left.1.4 \mathrm{~T}\right)$ or on a Bruker AMX-300 spectrometer $\left(300 \mathrm{MHz}\right.$ for ${ }^{1} \mathrm{H}$ and $75 \mathrm{MHz}$ for ${ }^{13} \mathrm{C}$ in a magnetic field of $7 \mathrm{~T}$ ). The chemical shifts are expressed in ppm with respect to tetramethylsilane (TMS) used as internal referant. IR spectra were recorded on a Perkin-Elmer FTIR 1760K spectrometer. UV-visible absorption spectra were recorded on a Cary 50 Varian spectrometer in dichloromethane $(20 \mu \mathrm{M})$. Emission spectra were recorded on a Shimadzu RF5301PC fluorimeter in dichloromethane $(5 \mu \mathrm{g} / \mathrm{ml})$. DSC thermograms were recorded with a MDSC 2950 CE device of TA Instruments. Optical analyses were carried out with a binocular microscope Laboval of Zeiss/AUS Jena, equipped with a turnable heating plate Mettler FP52 and a temperature control module Mettler FP5. The samples were subjected to a thermal scan from ambient to melting temperature and then cooled down by the same way. The scan rate was $10^{\circ} \mathrm{C} / \mathrm{min}$ in between thermal transitions and reduced to $1^{\circ} \mathrm{C} / \mathrm{min}$ in their neighbourhood. WAXS analyses were performed on the line X33 of EMBL (HASYLAB) on the ring DORIS III of Deutsches Elektronen Synchroton (DESY) in Hamburg. The wavelength of the incident X-ray beam was $0.154 \mathrm{~nm}$. The diffraction intensity curves at wide angles (WAXS) were recorded with a linear positioning detector. The domain $(s=(2 \sin \theta)$ $/ \lambda$ ) of this detector was calibrated with benzoic acid and varied from 17 to $36 \mathrm{~nm}^{-1}$. The WAXS intensity curves were normalised using the signal of an ionisation chamber situated in front of the sample. High resolution mass spectra (HRMS) were recorded in positive mode on a Qtof 2 (Micromass) equipped with an electrospray source. The compounds were dissolved $\left(10^{-5} \mathrm{M}\right)$ in a methanol/water mixture $(1: 1)$ acidified with formic acid (1\%). Measurements were recorded on the peak corresponding to the protonated form $(\mathrm{M}+1)^{+}$of the different compounds using Rhodamine $B$ as referent.

\section{Syntheses}

Condensation of 4-octyloxybenzaldehyde and 4-methylpyrimidine

A mixture of 4-octyloxybenzaldehyde $(10 \mathrm{mmol}, 2.34 \mathrm{~g})$ and 4-methylpyrimidine (10 mmol, $0.81 \mathrm{ml}$ ) was stirred for $1 \mathrm{~h}$ in a boiling aqueous solution of sodium hydroxide $(5 \mathrm{M}, 25 \mathrm{ml})$ and in the presence of tetrabutylammonium hydrogen sulfate $(1.0 \mathrm{mmol}$, 
$0.33 \mathrm{~g})$. The reaction medium was extracted with dichloromethane $(3 \times 25 \mathrm{ml})$. The organic phases were collected, dried on anhydrous magnesium sulfate and concentrated under reduced pressure. The solid residue was purified by recrystallisation in petroleum ether.

For the sake of clarity, yields and molecular characterization of all synthesized compounds are given separately (see hereafter).

\section{Condensation of 4-hydroxybenzaldehyde with 4-methylpyrimidine}

A mixture of 4-hydroxybenzaldehyde (10 mmol, $1.22 \mathrm{~g})$ and 4-methylpyrimidine (10 mmol, $0.81 \mathrm{ml}$ ) was stirred for $8 \mathrm{~h}$ in a boiling aqueous solution of sodium hydroxide $(5 \mathrm{M}, 25 \mathrm{ml})$ and in the presence of tetrabutylammonium hydrogen sulfate $(1 \mathrm{mmol}$, $0.33 \mathrm{~g}$ ). After cooling, a solid residue was isolated by suction filtration, washed with dichloromethane and dried. This solid was then dissolved in water and a solution of $5 \mathrm{M} \mathrm{HCl}$ was added dropwise until the formation of a precipitate, which was finally collected by filtration.

\section{Synthesis of compounds 3 to 9}

4-Hydroxybenzaldehyde (20 mmol, $2.44 \mathrm{~g}$ ) was stirred for $3 \mathrm{~h}$ in a boiling aqueous solution of sodium hydroxide $(5 \mathrm{M}, 50 \mathrm{ml})$ and in the presence of tetrabutylammonium hydrogen sulfate $(2 \mathrm{mmol}, 0.67 \mathrm{~g}$ ). The alkyl bromide was introduced after dissolution of the aldehyde and the mixture was stirred in a solution of $5 \mathrm{M}$ sodium hydroxide for $1 \mathrm{~h} .4,6$-Dimethylpyrimidine $(10 \mathrm{mmol}, 1.1 \mathrm{ml})$ was added afterwards and stirring was maintained for further $7 \mathrm{~h}$. After cooling, the solid compound was isolated by suction filtration. It was successively washed with petroleum ether, acetic acid and three times with acetone. Then, the product was purified by recrystallisation in petroleum ether.

The used alkyl bromides were bromooctane $(20 \mathrm{mmol}, 3.45 \mathrm{ml})$ for 3 , bromononane $(20 \mathrm{mmol}, 3.80 \mathrm{ml})$ for 4 , bromodecane $(20 \mathrm{mmol}, 4.10 \mathrm{ml})$ for 5 , bromoundecane (20 mmol, $4.46 \mathrm{ml})$ for 6 , bromododecane $(20 \mathrm{mmol}, 4.80 \mathrm{ml})$ for 7 , bromotetradecane (20 mmol, $6.0 \mathrm{ml})$ for 8 and bromohexadecane $(20 \mathrm{mmol}, 6.10 \mathrm{ml})$ for 9 .

\section{Synthesis of compound 10}

3-Hydroxybenzaldehyde (20 mmol, $2.44 \mathrm{~g}$ ), bromododecane $(20 \mathrm{mmol}, 4.80 \mathrm{ml}$ ) and 4,6-dimethylpyrimidine ( $10 \mathrm{mmol}, 1.10 \mathrm{ml}$ ) were stirred for $3 \mathrm{~h}$ in a boiling aqueous solution of sodium hydroxide $(5 \mathrm{M}, 50 \mathrm{ml})$ and in the presence of tetrabutylammonium hydrogen sulfate $(2 \mathrm{mmol}, 0.67 \mathrm{~g})$. After cooling, the solid compound 10 was isolated by filtration, washed with ethanol and purified by recrystallisation in ethanol.

\section{Synthesis of compound 11}

2-Hydroxybenzaldehyde (20 mmol, $2.13 \mathrm{ml}$ ) and bromododecane (20 mmol, $4.80 \mathrm{ml})$ were stirred for $1 \mathrm{~h}$ in a boiling aqueous solution of sodium hydroxide $(5 \mathrm{M}, 50 \mathrm{ml})$ and in the presence of tetrabutylammonium hydrogen sulfate $(2 \mathrm{mmol}, 0.67 \mathrm{~g}) .4,6$ Dimethylpyrimidine $(10 \mathrm{mmol}, 1.10 \mathrm{ml})$ was added and the solution was heated for $3 \mathrm{~h}$. After cooling, the mixture was extracted with dichloromethane $(3 \times 50 \mathrm{ml})$. The organic phases were then collected, dried on anhydrous magnesium sulfate and concentrated under reduced pressure. The resulting oil was treated with ethanol (20 $\mathrm{ml}$ ) and the whole was cooled in an ice bath. Compound 11 precipitated and could be 
isolated by filtration, washed three times with ethanol and purified by recrystallisation in acetonitrile.

\section{Synthesis of 3,4-didodecyloxybenzaldehyde}

3,4-Dihydroxybenzaldehyde ( $20 \mathrm{mmol}, 2.76 \mathrm{~g}$ ) and bromododecane (40 mmol, 9.60 $\mathrm{ml}$ ) were stirred for $3 \mathrm{~h}$ in a boiling aqueous solution of sodium hydroxide $(5 \mathrm{M}, 50 \mathrm{ml})$ and in the presence of tetrabutylammonium hydrogen sulfate $(2 \mathrm{mmol}, 0.67 \mathrm{~g})$. After cooling, 3,4-didodecyloxybenzaldehyde was isolated by filtration and washed with acetone.

\section{Synthesis of compound 12}

3,4-Dihydroxybenzaldehyde $(20 \mathrm{mmol}, 9.5 \mathrm{~g})$ and 4,6-dimethylpyrimidine $(10 \mathrm{mmol}$, $1.10 \mathrm{ml})$ were stirred for $6 \mathrm{~h}$ in a boiling aqueous solution of sodium hydroxide $(5 \mathrm{M}$, $50 \mathrm{ml}$ ) and in the presence of tetrabutylammonium hydrogen sulfate $(2 \mathrm{mmol}, 0.67 \mathrm{~g})$. After cooling, compound 12 was isolated by filtration, washed with acetone and purified by recrystallisation in acetone.

\section{Synthesis of 2-dodecyloxybenzaldehyde}

Salicylaldehyde $(20 \mathrm{mmol}, 2.13 \mathrm{ml})$ and bromododecane $(20 \mathrm{mmol}, 4.80 \mathrm{ml})$ were stirred for $6 \mathrm{~h}$ in a boiling aqueous solution of sodium hydroxide $(5 \mathrm{M}, 50 \mathrm{ml})$ and in the presence of tetrabutylammonium hydrogen sulfate $(2 \mathrm{mmol}, 0.67 \mathrm{~g})$. After cooling, the mixture was extracted with dichloromethane $(3 \times 50 \mathrm{ml})$. The organic phases were then collected, dried on anhydrous magnesium sulfate and concentrated under reduced pressure.

\section{Synthesis of 3-dodecyloxybenzaldehyde}

3-Hydroxybenzaldehyde (20 mmol, $2.44 \mathrm{~g}$ ) was dissolved in a boiling aqueous solution of sodium hydroxide $(5 \mathrm{M}, 50 \mathrm{ml})$ and in the presence of tetrabutylammonium hydrogen sulfate $(2 \mathrm{mmol}, 0.67 \mathrm{~g})$. Bromododecane $(20 \mathrm{mmol}, 4.80 \mathrm{ml})$ was introduced and the mixture was stirred for $30 \mathrm{~min}$. After cooling, the mixture was extracted with dichloromethane $(3 \times 50 \mathrm{ml})$. The organic phases were then collected, dried on anhydrous magnesium sulfate and concentrated under reduced pressure.

\section{Synthesis of compounds 13 and 14}

Crude dodecyloxybenzaldehyde (2-dodecyloxybenzaldehyde for 14 and 3-dodecyloxybenzaldehyde for $13 ; 20 \mathrm{mmol}, 5.80 \mathrm{~g}$ ) was introduced in small portions during $6 \mathrm{~h}$ to a boiling aqueous solution of sodium hydroxide $(5 \mathrm{M}, 50 \mathrm{ml})$ containing 2,5dimethylpyrazine $(10 \mathrm{mmol}, 1.0 \mathrm{ml})$ in the presence of tetrabutylammonium hydrogen sulfate $(2 \mathrm{mmol}, 0.67 \mathrm{~g})$. After cooling, the solid residue was isolated by filtration, washed and purified by recrystallisation in the same solvent, i.e., petroleum ether for 13 and ethanol for 14.

\section{4,6-Bis[2-(4-octyloxyphenyl)ethenyl]pyrimidine (3)}

Yield (after stirring for 8 h): 70\%. Transition temperatures: 49.2, 94.84, 113.78, $127.66^{\circ} \mathrm{C}$.

IR (KBr): 2955 - 2850 (aliphatic CH), 1636, 1514, $1258 \mathrm{~cm}^{-1}$. 
${ }^{1} \mathrm{H} \mathrm{NMR}\left(\mathrm{CDCl}_{3}, 300 \mathrm{MHz}\right): \delta=9.1\left(\mathrm{~s}, 1 \mathrm{H}\right.$, pyrimidine); $7.8\left(\mathrm{~d}, 2 \mathrm{H}\right.$, het- $\mathrm{CH}=, J_{\mathrm{HH}}=16$ $\mathrm{Hz}) ; 7.5\left(\mathrm{~d}, 4 \mathrm{H}\right.$, benz, $\left.J_{\mathrm{HH}}=9 \mathrm{~Hz}\right) ; 7.2\left(\mathrm{~s}, 1 \mathrm{H}\right.$, pyrimidine); $6.8\left(\mathrm{~d}, 4 \mathrm{H}\right.$, benz, $J_{\mathrm{HH}}=9$ $\mathrm{Hz}) ; 6.8\left(\mathrm{~d}, 2 \mathrm{H}, \mathrm{PheCH}=, J_{\mathrm{HH}}=16 \mathrm{~Hz}\right) ; 4.0\left(\mathrm{t}, 4 \mathrm{H},-\mathrm{OCH}_{2^{-}}, J_{\mathrm{HH}}=9 \mathrm{~Hz}\right) ; 1.8-0.9(\mathrm{~m}$, $30 \mathrm{H})$.

${ }^{13} \mathrm{C}$ NMR $\left(\mathrm{CDCl}_{3}\right): \delta=162.9 ; 160.3 ; 158.6 ; 136.6 ; 129.2 ; 128.2 ; 123.4 ; 115.9 ; 114.8$; $68.1 ; 31.8 ; 29.4 ; 29.3 ; 26.0 ; 22.7 ; 14.1$.

HRMS calc. for $\mathrm{C}_{36} \mathrm{H}_{49} \mathrm{~N}_{2} \mathrm{O}_{2}: 541.3794$; found: 541.3779 .

\section{4,6-Bis[2-(4-nonyloxyphenyl)ethenyl]pyrimidine (4)}

Yield: $70 \%$. Transition temperatures: $85.09,111.58,124.98,126.47^{\circ} \mathrm{C}$.

IR (KBr): 2955 - 2850 (aliphatic $\mathrm{CH}$ ), 1636, 1520, $1258 \mathrm{~cm}^{-1}$.

${ }^{1} \mathrm{H} \mathrm{NMR}\left(\mathrm{CDCl}_{3}, 300 \mathrm{MHz}\right): \delta=9.1(\mathrm{~s}, 1 \mathrm{H}$, pyrimidine $) ; 7.8\left(\mathrm{~d}, 2 \mathrm{H}\right.$, het-CH=, $J_{\mathrm{HH}}=16$ $\mathrm{Hz}) ; 7.5\left(\mathrm{~d}, 4 \mathrm{H}\right.$, benz, $\left.J_{\mathrm{HH}}=9 \mathrm{~Hz}\right) ; 7.2\left(\mathrm{~s}, 1 \mathrm{H}\right.$, pyrimidine); $6.8\left(\mathrm{~d}, 4 \mathrm{H}\right.$, benz, $J_{\mathrm{HH}}=9$ $\mathrm{Hz}) ; 6.8\left(\mathrm{~d}, 2 \mathrm{H}, \mathrm{PheCH}=, J_{\mathrm{HH}}=16 \mathrm{~Hz}\right) ; 4.0\left(\mathrm{t}, 4 \mathrm{H}, \mathrm{OCH}_{2}\right) ; 1.8-0.9(\mathrm{~m}, 34 \mathrm{H})$.

${ }^{13} \mathrm{C}$ NMR $\left(\mathrm{CDCl}_{3}\right): \delta=162.9 ; 160.3 ; 158.6 ; 136.6 ; 129.2 ; 128.2 ; 123.4 ; 115.9 ; 114.8$; $68.1 ; 31.9 ; 29.5 ; 29.4 ; 29.3 ; 29.2 ; 26.0 ; 22.7 ; 14.1$.

HRMS calc. for $\mathrm{C}_{38} \mathrm{H}_{53} \mathrm{~N}_{2} \mathrm{O}_{2}: 569.4107$; found: 569.4078 .

\section{4,6-Bis[2-(4-decyloxyphenyl)ethenyl]pyrimidine (5)}

Yield: $70 \%$. Transition temperatures: $76.72,108.32,124.04^{\circ} \mathrm{C}$.

IR (KBr): 2955 - 2850 (aliphatic CH), 1636, 1520, $1258 \mathrm{~cm}^{-1}$.

${ }^{1} \mathrm{H} \mathrm{NMR}\left(\mathrm{CDCl}_{3}, 300 \mathrm{MHz}\right): \delta=9.1(\mathrm{~s}, 1 \mathrm{H}$, pyrimidine $) ; 7.8\left(\mathrm{~d}, 2 \mathrm{H}\right.$, het- $\mathrm{CH}=, J_{\mathrm{HH}}=16$ $\mathrm{Hz}) ; 7.5\left(\mathrm{~d}, 4 \mathrm{H}\right.$, benz, $\left.J_{\mathrm{HH}}=9 \mathrm{~Hz}\right) ; 7.2\left(\mathrm{~s}, 1 \mathrm{H}\right.$, pyrimidine); $6.8\left(\mathrm{~d}, 4 \mathrm{H}\right.$, benz, $J_{\mathrm{HH}}=9$ $\mathrm{Hz}) ; 6.8\left(\mathrm{~d}, 2 \mathrm{H}, \mathrm{PheCH}=, J_{\mathrm{HH}}=16 \mathrm{~Hz}\right) ; 4.0\left(\mathrm{t}, 4 \mathrm{H}, \mathrm{OCH}_{2}\right) ; 1.8-0.9(\mathrm{~m}, 38 \mathrm{H})$.

${ }^{13} \mathrm{C}$ NMR $\left(\mathrm{CDCl}_{3}\right): \delta=162.9 ; 160.3 ; 158.6 ; 136.6 ; 129.7 ; 128.2 ; 123.4 ; 115.9 ; 114.8$; $68.1 ; 31.9 ; 29.6 ; 29.4 ; 29.3 ; 29.2 ; 26.0 ; 22.7 ; 14.1$.

HRMS calc. for $\mathrm{C}_{40} \mathrm{H}_{57} \mathrm{~N}_{2} \mathrm{O}_{2}: 597.4420$; found: 597.4404 .

\section{4,6-Bis[2-(4-undecyloxyphenyl)ethenyl]pyrimidine (6)}

Yield: $70 \%$. Transition temperatures: $101.55,115.10,120.64^{\circ} \mathrm{C}$.

IR (KBr): 2955 - 2850 (aliphatic CH), 1636; 1520, $1258 \mathrm{~cm}^{-1}$.

${ }^{1} \mathrm{H} \mathrm{NMR}\left(\mathrm{CDBr}_{3}, 300 \mathrm{MHz}\right.$, at $\left.70^{\circ} \mathrm{C}\right): \delta=9.1(\mathrm{~s}, 1 \mathrm{H}$, pyrimidine); $7.8(\mathrm{~d}, 2 \mathrm{H}$, het- $\mathrm{CH}=$, $\left.J_{\mathrm{HH}}=16 \mathrm{~Hz}\right) ; 7.5\left(\mathrm{~d}, 4 \mathrm{H}\right.$, benz, $\left.J_{\mathrm{HH}}=9 \mathrm{~Hz}\right) ; 7.2(\mathrm{~s}, 1 \mathrm{H}$, pyrimidine); $6.8(\mathrm{~d}, 4 \mathrm{H}$, benz, $\left.J_{\mathrm{HH}}=9 \mathrm{~Hz}\right) ; 6.8\left(\mathrm{~d}, 2 \mathrm{H}, \mathrm{PheCH}=, J_{\mathrm{HH}}=16 \mathrm{~Hz}\right) ; 4.0\left(\mathrm{t}, 4 \mathrm{H}, \mathrm{OCH}_{2}-\right) ; 1.8-0.9(\mathrm{~m}, 42 \mathrm{H})$.

${ }^{13} \mathrm{C} \mathrm{NMR}\left(\mathrm{CDBr}_{3}\right.$, at $\left.70^{\circ} \mathrm{C}\right): \delta=162.9 ; 160.3 ; 158.6 ; 136.6 ; 129.2 ; 128.2 ; 123.4$; $115.9 ; 114.8 ; 68.1 ; 31.9 ; 29.6 ; 29.4 ; 29.3 ; 29.2 ; 26.0 ; 22.7 ; 14.1$.

HRMS calc. for $\mathrm{C}_{42} \mathrm{H}_{61} \mathrm{~N}_{2} \mathrm{O}_{2}: 625.4733$; found: 625.4726 .

\section{4,6-Bis[2-(4-dodecyloxyphenyl)ethenyl]pyrimidine (7)}

Yield: $70 \%$. Transition temperature: $94.41,112.77,117.96^{\circ} \mathrm{C}$.

IR (KBr): 2955 - 2850 (aliphatic $\mathrm{CH}$ ), 1636, 1520, $1258 \mathrm{~cm}^{-1}$.

${ }^{1} \mathrm{H} \mathrm{NMR}\left(\mathrm{CDBr}_{3}, 300 \mathrm{MHz}\right.$, at $\left.70^{\circ} \mathrm{C}\right): \delta=9.1(\mathrm{~s}, 1 \mathrm{H}$, pyrimidine); $7.8(\mathrm{~d}, 2 \mathrm{H}$, het- $\mathrm{CH}=$, $\left.J_{\mathrm{HH}}=16 \mathrm{~Hz}\right) ; 7.5\left(\mathrm{~d}, 4 \mathrm{H}\right.$, benz, $\left.J_{\mathrm{HH}}=9 \mathrm{~Hz}\right) ; 7.2(\mathrm{~s}, 1 \mathrm{H}$, pyrimidine $) ; 6.8(\mathrm{~d}, 4 \mathrm{H}$, benz, $\left.J_{\mathrm{HH}}=9 \mathrm{~Hz}\right) ; 6.8\left(\mathrm{~d}, 2 \mathrm{H}, \mathrm{PheCH}=, J_{\mathrm{HH}}=16 \mathrm{~Hz}\right) ; 4.0\left(\mathrm{t}, 4 \mathrm{H}, \mathrm{OCH}_{2}-\right) ; 1.8-0.9(\mathrm{~m}, 46 \mathrm{H})$. 
${ }^{13} \mathrm{C} \mathrm{NMR}\left(\mathrm{CDBr}_{3}\right.$, at $\left.70^{\circ} \mathrm{C}\right): \delta=162.9 ; 160.3 ; 158.6 ; 136.6 ; 129.2 ; 128.2 ; 123.4$; $115.9 ; 114.8 ; 68.1 ; 31.9 ; 29.6 ; 29.4 ; 29.3 ; 29.2 ; 26.0 ; 22.7 ; 14.1$.

HRMS calc. for $\mathrm{C}_{44} \mathrm{H}_{65} \mathrm{~N}_{2} \mathrm{O}_{2}: 653.5046$; found: 653.5018 .

\section{4,6-Bis[2-(4-tetradecyloxyphenyl)ethenyl]pyrimidine (8)}

Yield: $70 \%$. Transition temperatures: $103.08,114.38,119.21^{\circ} \mathrm{C}$.

IR (KBr): 2955 - 2850 (aliphatic CH), 1636, 1520, $1258 \mathrm{~cm}^{-1}$.

${ }^{1} \mathrm{H} \mathrm{NMR}\left(\mathrm{CDBr}_{3}, 300 \mathrm{MHz}\right.$, at $\left.70^{\circ} \mathrm{C}\right): \delta=9.1(\mathrm{~s}, 1 \mathrm{H}$, pyrimidine); $7.8(\mathrm{~d}, 2 \mathrm{H}$, het- $\mathrm{CH}=$, $\left.J_{\mathrm{HH}}=16 \mathrm{~Hz}\right) ; 7.5\left(\mathrm{~d}, 4 \mathrm{H}\right.$, benz, $\left.J_{\mathrm{HH}}=9 \mathrm{~Hz}\right) ; 7.2(\mathrm{~s}, 1 \mathrm{H}$, pyrimidine); $6.8(\mathrm{~d}, 4 \mathrm{H}$, benz, $\left.J_{\mathrm{HH}}=9 \mathrm{~Hz}\right) ; 6.8\left(\mathrm{~d}, 2 \mathrm{H}, \mathrm{PheCH}=, \mathrm{JHH}_{\mathrm{HH}}=16 \mathrm{~Hz}\right) ; 4.0\left(\mathrm{t}, 4 \mathrm{H}, \mathrm{OCH}_{2}\right) ; 1.8-0.9(\mathrm{~m}, 54 \mathrm{H})$.

${ }^{13} \mathrm{C} \mathrm{NMR}\left(\mathrm{CDBr}_{3}\right.$, at $\left.70^{\circ} \mathrm{C}\right): \delta=162.9 ; 160.3 ; 158.6 ; 136.6 ; 129.2 ; 128.2 ; 123.4$; $115.9 ; 114.8 ; 68.1 ; 31.9 ; 29.6 ; 29.4 ; 29.3 ; 29.2 ; 26.0 ; 22.7 ; 14.1$.

HRMS calc. for $\mathrm{C}_{48} \mathrm{H}_{73} \mathrm{~N}_{2} \mathrm{O}_{2}: 709.5672$; found: 709.5638 .

\section{4,6-Bis[2-(4-hexadecyloxyphenyl)ethenyl]pyrimidine (9)}

Yield: $70 \%$. Transition temperatures: $108.82,114.88,117.38^{\circ} \mathrm{C}$.

IR (KBr): 2955 - 2850 (aliphatic CH), 1636, 1520, $1258 \mathrm{~cm}^{-1}$.

${ }^{1} \mathrm{H} \mathrm{NMR}\left(\mathrm{CDBr}_{3}, 300 \mathrm{MHz}\right.$, at $\left.70^{\circ} \mathrm{C}\right): \delta=9.1(\mathrm{~s}, 1 \mathrm{H}$, pyrimidine); $7.8(\mathrm{~d}, 2 \mathrm{H}$, het- $\mathrm{CH}=$, $\left.J_{\mathrm{HH}}=16 \mathrm{~Hz}\right) ; 7.5\left(\mathrm{~d}, 4 \mathrm{H}\right.$, benz, $\left.J_{\mathrm{HH}}=9 \mathrm{~Hz}\right) ; 7.2(\mathrm{~s}, 1 \mathrm{H}$, pyrimidine $) ; 6.8(\mathrm{~d}, 4 \mathrm{H}$, benz, $\left.J_{\mathrm{HH}}=9 \mathrm{~Hz}\right) ; 6.8\left(\mathrm{~d}, 2 \mathrm{H}, \mathrm{PheCH}=, J_{\mathrm{HH}}=16 \mathrm{~Hz}\right) ; 4.0\left(\mathrm{t}, 4 \mathrm{H}, \mathrm{OCH}_{2}-\right) ; 1.8-0.9(\mathrm{~m}, 62 \mathrm{H})$.

${ }^{13} \mathrm{C} \mathrm{NMR}\left(\mathrm{CDBr}_{3}\right.$, at $\left.70^{\circ} \mathrm{C}\right): \delta=162.9 ; 160.3 ; 158.6 ; 136.6 ; 129.2 ; 128.2 ; 123.4$; $115.9 ; 114.8 ; 68.1 ; 31.9 ; 29.6 ; 29.4 ; 29.3 ; 29.2 ; 26.0 ; 22.7 ; 14.1$.

HRMS calc. for $\mathrm{C}_{52} \mathrm{H}_{81} \mathrm{~N}_{2} \mathrm{O}_{2}: 765.6298$; found: 765.6284 .

\section{4,6-Bis[2-(3-dodecyloxyphenyl)ethenyl]pyrimidine (10)}

Yield: $30 \%$; m.p.: $79.22^{\circ} \mathrm{C}$.

IR (KBr): 2955 - 2850 (aliphatic CH), 1606, 1580, $1258 \mathrm{~cm}^{-1}$.

${ }^{1} \mathrm{H} \mathrm{NMR}\left(\mathrm{CDCl}_{3}, 300 \mathrm{MHz}\right): \delta=9.1(\mathrm{~s}, 1 \mathrm{H}$, pyrimidine $) ; 7.9\left(\mathrm{~d}, 2 \mathrm{H}\right.$, het- $\mathrm{CH}=, J_{\mathrm{HH}}=16$ $\mathrm{Hz}) ; 7.4-6.9\left(\mathrm{~m}, 8 \mathrm{H}\right.$, benz, $J_{\mathrm{HH}}=9$ and $\left.2 \mathrm{~Hz}\right) ; 7.2(\mathrm{~s}, 1 \mathrm{H}$, pyrimidine); $7.05(\mathrm{~d}, 2 \mathrm{H}$, $\left.\mathrm{PheCH}=, J_{\mathrm{HH}}=16 \mathrm{~Hz}\right) ; 4.0\left(\mathrm{t}, 4 \mathrm{H}, \mathrm{OCH}_{2^{-}}\right) ; 1.8-0.9(\mathrm{~m}, 46 \mathrm{H})$.

${ }^{13} \mathrm{C}$ NMR $\left(\mathrm{CDCl}_{3}\right): 162.7 ; 159.5 ; 158.7 ; 137.0 ; 129.8 ; 126.0 ; 120.2 ; 115.8 ; 113.2$; $68.1 ; 31.9 ; 29.6 ; 29.4 ; 29.4 ; 29.3 ; 26.1 ; 22.7 ; 14.1$.

HRMS calc. for $\mathrm{C}_{44} \mathrm{H}_{65} \mathrm{~N}_{2} \mathrm{O}_{2}: 653.5046$; found: 653.5014 .

\section{4,6-Bis[2-(2-dodecyloxyphenyl)ethenyl]pyrimidine (11)}

Yield: $25 \%$; m.p.: $58.57^{\circ} \mathrm{C}$.

IR (KBr): 3033 - 2850, 1626, 1572, 1455, $1247 \mathrm{~cm}^{-1}$.

${ }^{1} \mathrm{H} \mathrm{NMR}\left(\mathrm{CDCl}_{3}, 300 \mathrm{MHz}\right): \delta=9.1\left(\mathrm{~s}, 1 \mathrm{H}\right.$, pyrimidine); $8.2\left(\mathrm{~d}, 2 \mathrm{H}\right.$, het- $\mathrm{CH}=, J_{\mathrm{HH}}=16$ $\mathrm{Hz}) ; 7.6\left(\mathrm{~m}, 2 \mathrm{H}\right.$, benz, $\left.J_{\mathrm{HH}}=9 \mathrm{~Hz}\right), 7.3\left(\mathrm{~m}, 4 \mathrm{H}\right.$, benz, $\left.J_{\mathrm{HH}}=9 \mathrm{~Hz}\right), 7.2(\mathrm{~s}, 1 \mathrm{H}$, pyrimidine); $7.2\left(\mathrm{~d}, 2 \mathrm{H}, \mathrm{PheCH}=, J_{\mathrm{HH}}=16 \mathrm{~Hz}\right) ; 7.0\left(\mathrm{~m}, 2 \mathrm{H}\right.$, benz, $\left.J_{\mathrm{HH}}=9 \mathrm{~Hz}\right) ; 4.0(\mathrm{t}$, $\left.4 \mathrm{H}, \mathrm{OCH}_{2}-\right) ; 1.8-0.9(\mathrm{~m}, 46 \mathrm{H})$.

${ }^{13} \mathrm{C} \mathrm{NMR}\left(\mathrm{CDCl}_{3}\right): \delta=163.3 ; 158.8 ; 157.6 ; 132.4 ; 130.4 ; 128.5 ; 126.7 ; 124.9 ; 120.6$; $115.9 ; 112.1 ; 68.5 ; 31.9 ; 29.7 ; 29.7 ; 29.5 ; 29.3 ; 29.3 ; 26.2 ; 22.7 ; 14.1$.

HRMS calc. for $\mathrm{C}_{44} \mathrm{H}_{65} \mathrm{~N}_{2} \mathrm{O}_{2}: 653.5046$; found: 653.5016 . 


\section{3,4-Didodecyloxybenzaldehyde}

Yield: $60 \%$; m.p.: $70-71^{\circ} \mathrm{C}$.

IR (KBr): 2955 - 2850 (aliphatic CH), 1687, 1510, 1467, $1279 \mathrm{~cm}^{-1}$.

${ }^{1} \mathrm{H} \mathrm{NMR}\left(\mathrm{CDCl}_{3}, 60 \mathrm{MHz}\right): \delta=9.75(\mathrm{~s}, 1 \mathrm{H}, \mathrm{HCO}) ; 7.3-6.8\left(\mathrm{~m}, 3 \mathrm{H}\right.$, benz, $\left.J_{\mathrm{HH}}=9 \mathrm{~Hz}\right)$; $4.0\left(\mathrm{t}, 2 \mathrm{H}, \mathrm{OCH}_{2^{-}}, J_{\mathrm{HH}}=9 \mathrm{~Hz}\right) ; 1.4-0.9\left(\mathrm{~m}, 42 \mathrm{H}, \mathrm{J}_{\mathrm{HH}}=9 \mathrm{~Hz}\right)$.

\section{4,6-Bis[2-(3,4-didodecyloxyphenyl)ethenyl]pyrimidine (12)}

Yield: $70 \%$. Transition temperatures: $78.15,87.47^{\circ} \mathrm{C}$.

IR (KBr): 2995 - 2850, 1630, 1578, 1467, $1256 \mathrm{~cm}^{-1}$.

${ }^{1} \mathrm{H} \mathrm{NMR}\left(\mathrm{CDCl}_{3}, 300 \mathrm{MHz}\right): \delta=9.1\left(\mathrm{~s}, 1 \mathrm{H}\right.$, pyrimidine); $7.8\left(\mathrm{~d}, 2 \mathrm{H}\right.$, het- $\mathrm{CH}=, J_{\mathrm{HH}}=16$ $\mathrm{Hz}) ; 7.2\left(\mathrm{~s}, 1 \mathrm{H}\right.$, pyrimidine); $7.1-6.9\left(\mathrm{~m}, 6 \mathrm{H}\right.$, benz, $\mathrm{J}_{\mathrm{HH}}=9$ and $\left.2 \mathrm{~Hz}\right) ; 6.8(\mathrm{~d}, 2 \mathrm{H}$, $\left.\mathrm{PheCH}=, J_{\mathrm{HH}}=16 \mathrm{~Hz}\right) ; 4.0\left(\mathrm{~m}, 8 \mathrm{H}, \mathrm{OCH}_{2}\right) ; 1.8-0.9(\mathrm{~m}, 92 \mathrm{H})$.

${ }^{13} \mathrm{C} \mathrm{NMR}\left(\mathrm{CDCl}_{3}\right): \delta=162.9 ; 158.6 ; 150.7 ; 149.2 ; 136.9 ; 128.6 ; 123.6 ; 121.8 ; 115.5$; 113.2; 112.1; 69.3; 69.1; 31.9; 29.7; 29.7; 29.5; 29.4; 29.4; 29.3; 29.2; 26.1; 22.7; 14.1.

HRMS calc. for $\mathrm{C}_{68} \mathrm{H}_{113} \mathrm{~N}_{2} \mathrm{O}_{4}: 1021.8700$; found: 1021.8730 .

\section{2-Dodecyloxybenzaldehyde}

Yield: 95\%. IR (film): 3000 - 2900 (aliphatic $\mathrm{CH}$ ), $1669 \mathrm{~cm}^{-1}$ (CHO-).

${ }^{1} \mathrm{H} \mathrm{NMR}\left(\mathrm{CDCl}_{3}, 60 \mathrm{MHz}\right): \delta=9.75(\mathrm{~s}, 1 \mathrm{H}, \mathrm{HCO}) ; 7.3-6.8\left(\mathrm{~m}, 4 \mathrm{H}\right.$, benz, $\left.J_{\mathrm{HH}}=9 \mathrm{~Hz}\right)$; $4.0\left(\mathrm{t}, 2 \mathrm{H}, \mathrm{OCH}_{2^{-}}, J_{\mathrm{HH}}=9 \mathrm{~Hz}\right) ; 1.4-0.9\left(\mathrm{~m}, 21 \mathrm{H}, \mathrm{J}_{\mathrm{HH}}=9 \mathrm{~Hz}\right)$.

\section{3-Dodecyloxybenzaldehyde}

IR (film): 3000 - 2900 (aliphatic CH), $1669 \mathrm{~cm}^{-1}$ (CHO-).

${ }^{1} \mathrm{H} \mathrm{NMR}\left(\mathrm{CDCl}_{3}, 60 \mathrm{MHz}\right): \delta=9.75(\mathrm{~s}, 1 \mathrm{H}, \mathrm{HCO}) ; 7.3-6.8\left(\mathrm{~m}, 4 \mathrm{H}\right.$, benz, $\left.J_{\mathrm{HH}}=9 \mathrm{~Hz}\right)$; $4.0\left(\mathrm{t}, 2 \mathrm{H}, \mathrm{OCH}_{2^{-}}, \mathrm{J}_{\mathrm{HH}}=9 \mathrm{~Hz}\right) ; 1.4-0.9\left(\mathrm{~m}, 21 \mathrm{H}, \mathrm{J}_{\mathrm{HH}}=9 \mathrm{~Hz}\right)$.

\section{2,5-Bis[2-(3-dodecyloxyphenyl)ethenyl]pyrazine (13)}

Yield: $30 \%$; m.p.: $98.3^{\circ} \mathrm{C}$.

IR (KBr): 2919 - 2850, 1577, $1263 \mathrm{~cm}^{-1}$.

${ }^{1} \mathrm{H}$ NMR $\left(\mathrm{CDCl}_{3}, 300 \mathrm{MHz}\right): \delta=8.6(\mathrm{~s}, 1 \mathrm{H}$, pyrazine $) ; 7.7\left(\mathrm{~d}, 2 \mathrm{H}\right.$, het- $\mathrm{CH}=, J_{\mathrm{HH}}=16$ $\mathrm{Hz}) ; 7.3-6.8\left(\mathrm{~m}, 12 \mathrm{H}\right.$, benz, $J_{\mathrm{HH}}=8$ and $\left.16 \mathrm{~Hz}\right) ; 4.0\left(\mathrm{t}, 4 \mathrm{H}, \mathrm{OCH}_{2}-\right) ; 1.8-0.9(\mathrm{~ms}$, $46 \mathrm{H})$.

${ }^{13} \mathrm{C} \mathrm{NMR}\left(\mathrm{CDCl}_{3}\right): \delta=159.5 ; 149.0 ; 143.3 ; 137.6 ; 134.4 ; 129.7 ; 124.2 ; 119.9 ; 115.3$; $112.8 ; 68.0 ; 31.9 ; 29.7 ; 29.7 ; 29.6 ; 29.4 ; 29.4$. $29.3 ; 26.1 ; 22.7 ; 14.1$.

HRMS calc. for $\mathrm{C}_{44} \mathrm{H}_{65} \mathrm{~N}_{2} \mathrm{O}_{2}: 653.5046$; found: 653.5019 .

\section{2,5-Bis[2-(2-dodecyloxyphenyl)ethenyl]pyrazine (14)}

Yield: $30 \%$; m.p.: $90^{\circ} \mathrm{C}$.

IR (KBr): 2919 - 2850, 1587, $1269 \mathrm{~cm}^{-1}$.

${ }^{1} \mathrm{H}$ NMR $\left(\mathrm{CDCl}_{3}, 300 \mathrm{MHz}\right): \delta=8.6\left(\mathrm{~s}, 1 \mathrm{H}\right.$, pyrazine); $8.0\left(\mathrm{~d}, 2 \mathrm{H}\right.$, het- $\mathrm{CH}=, J_{\mathrm{HH}}=16$ $\mathrm{Hz}) ; 7.6\left(\mathrm{~d}, 2 \mathrm{H}\right.$, benz, $\left.\mathrm{J}_{\mathrm{HH}}=8 \mathrm{~Hz}\right) ; 7.3\left(\mathrm{~m}, 4 \mathrm{H}\right.$, benz, $\left.\mathrm{J}_{\mathrm{HH}}=9 \mathrm{~Hz}\right) ; 7.3(\mathrm{~d}, 2 \mathrm{H}, \mathrm{PheCH}=$, $\left.J_{\mathrm{HH}}=16 \mathrm{~Hz}\right) ; 6.9\left(\mathrm{~m}, 4 \mathrm{H}\right.$, benz, $\left.J_{\mathrm{HH}}=9 \mathrm{~Hz}\right) ; 4.0\left(\mathrm{t}, 4 \mathrm{H}, \mathrm{OCH}_{2}-\right) ; 1.8-0.9(\mathrm{~ms}, 46 \mathrm{H})$. 
${ }^{13} \mathrm{C} \mathrm{NMR}\left(\mathrm{CDCl}_{3}\right): \delta=157.3 ; 149.5 ; 143.0 ; 129.8 ; 129.6 ; 128.0 ; 125.5 ; 125.1 ; 120.6$; $112.0 ; 68.5 ; 31.9 ; 29.7 ; 29.7 ; 29.5 ; 29.4 ; 29.3 ; 26.2 ; 22.7 ; 14.1$.

HRMS calc. for $\mathrm{C}_{44} \mathrm{H}_{65} \mathrm{~N}_{2} \mathrm{O}_{2}: 653.5046$; found: 653.5019 .

Acknowledgement: SMPC is much indebted to the Région Wallonne and the Fond Social Européen for support in the frame of Objectif 1 - Hainaut: Materia Nova. SMPC thanks the 'Services Fédéraux des Affaires Scientifiques, Techniques et Culturelles' for general support in the frame of PAI-5/03. L.P. is grateful to F.R.I.A. for his Ph.D. grant. Authors are very much indebted to Dr. St. Hocquet for performing the WAXS experiments in Hamburg.

[1] Cornil, J.; Brédas, J. L.; Chimie Nouvelle 2000, 18, 3183.

[2] Greenham, N. C.; Moratti, S. C.; Bradley, D. D. C.; Friend, R. H.; Holmes, A. B.; Nature 1993, 365, 268.

[3] Kraft, A.; Grimsdale, A. C.; Holmes, A. B.; Angew. Chem. Int. Ed. 1998, 37, 403.

[4] Sariciftci, N. S.; "Primary Photoexcitations in Conjugated Polymers: Molecular Exciton versus Semiconductor Band Model", World Scientific Ed., Singapore 1997.

[5] Burroughes, J. H.; Bradley, D. D. C.; Brown, A. R.; Marks, R. N.; Friend, R. H.; Burn, P. L.; Holmes, A. B.; Nature 1990, 347, 359.

[6] Sheats, J. R.; Antoniadis, H.; Hueschen, M.; Leonard, W.; Miller, J.; Moon, R.; Roitman, D.; Stocking, A.; Science 1996, 273, 884.

[7] Friend, R. H.; Gymer, R. W.; Holmes, A. B.; Burroughes, J. H.; Marks, R. N.; Taliani, C.; Bradley, D. D. C.; dos Santos, D. A.; Bredas, J. L.; Lögdlund, M.; Salaneck, W. R.; Nature 1999, 397, 121.

[8] Halls, J. J. M.; Walsh, C. A.; Greenham, N. C.; Marseglia, E. A.; Friend, R. H.; Moratti, S. C.; Holmes, A. B.; Nature 1995, 376, 498.

[9] Halls, J. J. M.; Cornil, J.; dos Santos, D. A.; Silbey, R.; Wang, D. H.; Holmes, A. B.; Bredas, J. L.; Friend, R. H.; Phys. Rev. B 1999, 60, 5721.

[10] Pascal, L.; Vanden Eynde, J. J.; Van Haverbeke, Y.; Dubois, P.; Michel, A.; Rant, U.; Zojer, E.; Leising, G.; Van Dorn, L.; Gruhn, N. E.; Cornil, J.; Bredas, J. L.; J. Phys. Chem. B 2002, 106, 6442.

[11] Lane, P. A.; Mellor, H.; Martin, S. J.; Hagler, T. W.; Bleyer, A.; Bradley, D. D. C.; Chem. Phys. 2000, 257, 41.

[12] Cornil, J.; Beljonne, D.; dos Santos, D. A.; Brédas, J. L.; Synth. Met. 1996, 76, 101.

[13] Smolenyak, P.; Peterson, R.; Nebesny, K.; Törker, M.; O’Brien, D. F.; Armstrong, N. R.; J. Am. Chem. Soc. 1999, 121, 8628.

[14] Friend, R. H.; Burroughes, J. H.; Shimoda, T.; Physics World, June 1999, 35.

[15] Verma, A. R.; Krishna, P.; "Polymorphism and Polytipism in Crystals", John Wiley \& Sons Inc., New York 1996.

[16] Collins, P. J.; Michaël, H.; "Introduction to Liquid Crystals Chemistry and Physics", Taylor and Francis Ltd., London 1997.

[17] Tschierske, C.; J. Mater. Chem. 1998, 8, 1485. 
[18] Chen, W.; Wunderlich, B.; Macromol. Chem. Phys. 1999, 200, 283.

[19] Mataka, S.; Misumi, O.; Lin, W. H.; Tashiro, M.; Takahashi, K.; Tori, A.; J. Heterocycl. Chem. 1992, 29, 87.

[20] Fu, D. K.; Xu, B.; Swager, T. M.; Tetrahedron 1997, 53, 15494.

[21] Vanden Eynde, J. J.; Pascal, L.; Van Haverbeke, Y.; Dubois, P.; Synth. Commun. 2001, 31, 3167.

[22] Vanden Eynde, J. J.; Mailleux, I.; Synth. Commun. 2001, 31, 1.

[23] Haroutounian, S.; Katzenellenbogen, J.; Tetrahedron 1995, 51, 1585.

[24] Geissman, T. A.; Org. Reactions 1944, 2, 94.

[25] Karabunarliev, S.; Baumgarten, M.; Tyutyulkov, N.; Müllen, K.; J. Phys. Chem. 1994, 98, 11892. 